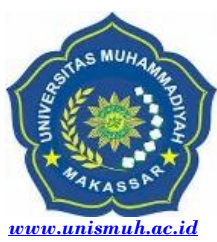

\title{
Meningkatkan Hasil Belajar Pendidikan Kewarganegaraan Melalui Penerapan Model Pembelajaran Kooperatif Tipe Think Pair Share Siswa Sekolah Menengah Atas Negeri 4 Polewali Mandar Provinsi Sulawesi Barat
}

\author{
Mustapa Tutu \\ Sekolah Menengah Atas Negeri 4 Polewali dan Istitut Agama Islam Darud Da'wah Wal Irsyad Polewali Mandar \\ Indonesia \\ mustapatutu@gmail.com
}

\begin{abstract}
Abstract. This research is a Classroom Action Research that aims to improve the learning outcomes of Civics through the application of Think Pair Share (TPS) cooperative learning models. The subjects in this class action research were Class X Students of SMA Negeri 4 Polewali, Polewali Mandar Regency with 23 students consisting of 9 men and 14 women. This research was conducted in 2 (two) cycles. Data collection was carried out using observation sheets and tests in the form of descriptions that were carried out in each cycle. The collected data were analyzed using descriptive analysis both quantitatively and qualitatively. The results showed mastery learning in the first cycle of $39.1 \%$ included in the complete category and $60.9 \%$ included in the incomplete category, in the second cycle $86.9 \%$ included in the complete category and $13.0 \%$ in the incomplete category. The average score of the test results of each cycle can be seen in the first cycle with an average score of 56.3 in the medium category. And in cycle II with an average score of 73.0 in the high category. From this study shows that the application of the Think Pair Share (TPS) type of cooperative learning can improve the learning outcomes of Civics in Class X Students of SMA Negeri 4 Polewali Mandar.
\end{abstract}

Keywords: Outcomes, Students, Think Pair Share

\begin{abstract}
Abstrak. Penelitian ini merupakan Penelitian Tindakan Kelas (Classroom Action Research) yang bertujuan untuk meningkatkan hasil belajar PKn melalui penerapan model pembelajaran kooperatif tipe Think Pair Share (TPS). Subjek dalam penelitian tindakan kelas ini adalah Siswa Kelas X SMA Negeri 4 Polewali Kabupaten Polewali Mandar dengan jumlah Siswa 23 orang yang terdiri dari 9 orang laki-laki dan 14 orang perempuan. Penelitian ini dilaksanakan dalam 2 (dua) siklus. Pengumpulan data dilakukan dengan menggunakan lembar observasi dan tes dalam bentuk uraian yang dilaksanakan pada setiap siklus. Data yang terkumpul dianalisis dengan menggunakan analisis deskriptif baik secara kuantitatif maupun secara kualitatif. Hasil penelitian menunjukkan ketuntasan belajar pada siklus I sebesar 39,1 \% yang masuk kategori tuntas dan 60,9\% yang masuk kategori tidak tuntas, pada siklus II sebesar $86,9 \%$ yang masuk kategori tuntas dan 13,0 \% yang masuk kategori tidak tuntas. Adapun skor rata-rata hasil tes dari setiap siklus dapat dilihat pada siklus I dengan skor rata-rata 56,3 berada dalam kategori sedang. Dan pada siklus II dengan skor rata-rata 73,0 berada dalam kategori tinggi. Dari penelitian ini menunjukkan bahwa penerapan model pembelajaran kooperatif tipe Think Pair Share (TPS) dapat meningkatkan hasil belajar PKn pada Siswa Kelas X SMA Negeri 4 Polewali Mandar.
\end{abstract}

Kata kunci: Hasil Belajar, Siswa, Think Pair Share 


\section{PENDAHULUAN}

Pendidikan adalah investasi sumber daya manusia jangka panjang yang mempunyai nilai strategis bagi kelangsungan peradaban manusia di dunia. Oleh sebab itu, hampir semua negara menempatkan pendidikan sebagai sesuatu yang penting dan utama dalam konteks pembangunan bangsa dan negara. Begitu juga Indonesia menempatkan pendidikan sebagai sesuatu yang penting dan utama. Hal ini dapat dilihat dari isi pembukaan UUD 1945 alinea IV yang menegaskan bahwa salah satu tujuan nasional bangsa Indonesia adalah mencerdaskan kehidupan bangsa. Oleh karena itu pemerintah mengadakan berbagai upaya dalam meningkatkan sumber daya manusia. Hal tersebut sesuai dengan perumusan tujuan pendidikan yang terdapat di dalam Undang-undang Republik Indonesia No. 20 tahun 2003 tentang Sistem Pendidikan Nasional pasal 3 dijelaskan bahwa Pendidikan nasional berfungsi mengembangkan kemampuan dan membentuk watak serta peradaban bangsa yang bermartabat dalam rangka mencerdaskan kehidupan bangsa, bertujuan untuk berkembangnya potensi Siswa agar menjadi manusia yang beriman dan bertakwa kepada Tuhan Yang Maha Esa, berakhlak mulia, sehat, berilmu, cakap, kreatif, mandiri, dan menjadi warga negara yang demokratis serta bertanggung jawab". Sehubungan dengan pencapaian tujuan pendidikan nasional, Pemerintah telah berupaya mengambil kebijakan dan langkah-langkah untuk meningkatkan mutu pendidikan di sekolah antara lain diadakan perubahan dan penyesuaian kurikulum disemua jenjang pendidikan seperti penataran guru-guru, pengadaan buku paket, penambahan sarana dan prasarana untuk kegiatan belajar mengajar, dan adanya program pendidikan gratis. Pendidikan gratis adalah membebaskan segala biaya pendidikan bagi Siswa/ orang tua Siswa yang berkaitan dengan proses belajar mengajar dan kegiatan pembangunan sekolah. Pendidikan gratis dilaksanakan pada tingkat SD/MI, SMP/MTS, SMA/MA/SMK negeri/swasta. Pendidikan gratis berfungsi untuk memberi kesempatan yang seluas-luasnya kepada usia belajar guna mendapatkan pendidikan yang layak.
Selain itu pemerintah dan pemerintah daerah menjamin terselenggaranya program wajib belajar 9 tahun tanpa memungut biaya. Program wajib belajar diselenggarakan untuk memberikan pelayanan pendidikan kepada warga negara Indonesia tanpa membedakan latar belakang agama, suku, sosial, budaya dan ekonomi. Setiap warga negara Indonesia usia wajib belajar berhak mendapatkan pelayanan pendidikan yang bermutu dan orang tua/ walinya berkewajiban memberi kesempatan kepada anaknya untuk mendapatkan pendidikan dasar. Hal tersebut sesuai dengan Peraturan Pemerintah Republik Indonesia No. 47 tahun 2008 tentang Wajib Belajar pasal 2 dijelaskan bahwa wajib belajar bertujuan memberikan pendidikan minimal bagi warga negara Indonesia untuk dapat mengembangkan potensi dirinya agar dapat hidup mandiri di dalam masyarakat atau melanjutkan pendidikan ke jenjang yang lebih tinggi.

Pendidikan sekarang berkembang pesat sejalan dengan berkembangnya ilmu pengetahuan dan teknologi. Jadi, seorang guru dituntut bagaimana usahanya untuk membentuk Siswa menjadi manusia yang mempunyai sumber daya yang bagus sehingga mampu bersaing di era sekarang ini. Mata pelajaran di sekolah dasar merupakan program untuk menanamkan dan mengembangkan pengetahuan, keterampilan, sikap dan nilai kepada Siswa.

Pendidikan Kewarganegaraan

(PKn) merupakan salah satu mata pelajaran yang dapat membentuk diri yang beragam dari segi agama, sosio-kultural, bahasa, usia, untuk menjadi warga negara yang cerdas, terampil dan berkarakter yang dilandasi UUD 1945. Pendidikan kewarganegaraan diharapkan antara lain dapat mendidik warga negara Indonesia menjadi warga negara yang baik. Dikatakan warga negara yang baik apabila warga negara tersebut mampu memenuhi ketentuan kodrat yang telah tertanam dalam diri manusia itu sendiri. Di Indonesia dikatakan baik adalah manusia Indonesia yang bermoral pancasila. Pendidikan kewarganegaraan sangat penting bagi kehidupan manusia Indonesia, karena pendidikan kewarganegaraan mengandung berbagai 
pendidikan yang baik untuk diterapkan di masyarakat. Tanpa adanya pendidikan kewarganegaraan interaksi dengan orang lain tidak akan terjalin dengan baik.

Tidak bisa dipungkiri bahwa tujuan utama kegiatan belajar mengajar di dalam kelas adalah agar Siswa dapat menguasai bahan-bahan belajar sesuai dengan tujuan-tujuan yang telah ditetapkan. Namun demikian, kenyataan menunjukkan bahwa setelah kegiatan belajar mengajar berakhir masih ada saja Siswa yang tidak menguasai materi pelajaran dengan baik. Hal ini menunjukkan Siswa tidak memiliki pemahaman yang kuat untuk menginternalisasikan bahan-bahan yang dipelajari ke dalam suatu konsep/ pengertian secara menyeluruh. Oleh karena itu seorang guru harus melakukan berbagai upaya mulai dari penyusunan rencana pembelajaran, penggunaan strategi belajar mengajar yang relevan, pemilihan model/ metode serta media pembelajaran secara bervariasi dalam proses pembelajaran.

Hasil awal observasi peneliti pada siswa Kelas $X \quad$ SMA Negeri 4 Polewali Kabupaten Polewali Mandar nilai ulangan harian mata pelajaran PKn hanya mencapai rata-rata 67,00 yang masih berada di bawah nilai Kriteria Ketuntasan Minimun (KKM) oleh sekolah tersebut yaitu 78,00 dari skor ideal 100 sehingga perlu ditingkatkan.

Berdasarkan permasalahan yang ditemukan, maka perlu langkah-langkah untuk memperbaiki pembelajaran di kelas dengan melakukan inovasi pembelajaran yang lebih memberdayakan dan dorongan Siswa mengkonstruksi pengetahuannya sendiri, aktif dalam proses belajar mengajar, sehingga dapat mengorganisir materi pelajaran, maka penggunaan model yang tepat berdasarkan tujuan dan situasi Siswa sangatlah dibutuhkan. Oleh sebab itu, model pembelajaran kooperatif sebagai suatu cara yang mengantarkan pada suatu tujuan harus benar-benar diperhatikan guru. Model pembelajaran kooperatif lebih mengutamakan kerjasama di antara Siswa untuk mencapai tujuan pembelajaran. Pembelajaran kooperatif terdiri dari beberapa tipe antara lain; tipe STAD, Jigsaw, TGT, dan tipe structural yaitu TPS dan NHT. Setiap tipe mempunyai langkah-langkah khusus serta mempunyai kelebihan dan kelemahan. Maka untuk meningkatkan hasil belajar PKn akan diterapkan pembelajaran kooperatif tipe Think Pair Share (TPS). Think Pair Share (TPS) merupakan suatu cara yang efektif untuk membuat variasi suasana pola diskusi kelas dan dapat memberi siswa lebih banyak waktu berpikir, untuk merespon dan saling membantu.

\section{METODE PENELITIAN}

Jenis penelitian ini adalah penelitian tindakan kelas (Classroom Action Research) yang dilakukan dengan dua siklus, yang disetiap siklus terdiri dari 4 (empat) tahapan yaitu: (1) perencanaan, (2) pelaksanaan, (3) observasi dan evaluasi, (4) refleksi. Lokasi penelitian tindakan kelas ini adalah di kelas $X$ SMA Negeri 4 Polewali Kabupaten Polewali Mandar. Subjek dalam penelitian tindakan kelas ini adalah Siswa Kelas $X \quad$ SMA Negeri 4 Polewali Kabupaten Polewali Mandar dengan jumlah Siswa 23 orang yang terdiri dari 9 orang laki-laki dan 14 orang perempuan pada tahun pelajaran 2018/2019.

Penelitian tindakan kelas ini dilaksanakan pada tahun pelajaran 2018/2019 yang terbagi dalam dua siklus, tiap siklus dilaksanakan sesuai dengan perubahan-perubahan yang ingin dicapai. Setiap siklus dilaksanakan sebanyak 3 kali pertemuan termasuk pelaksanaan tes siklus I dan tes siklus II yang semuanya menggunakan model pembelajaran kooperatif tipe Think Pair Share (TPS). Dan setiap siklus terdiri dari 4 tahapan yaitu :1) Perencanaan 2) Pelaksanaan 3) Observasi 4) Refleksi. Instrumen pengumpulan data dalam penelitian ini meliputi tes dan observasi. (a) Tes menggunakan butir soal/ instrument soal untuk mengukur hasil belajar Siswa. (b) Observasi untuk mengamati aktivitas Siswa selama kegiatan pembelajaran dengan menggunakan lembar observasi. Hal ini dilakukan untuk mengetahui kesesuaian antara perencanaan dengan pelaksanaan tindakan.

Pengumpulan data pada penelitian ini menggunakan data kualitatif dan data kuantitatif. Teknik pengambilan data dengan menggunakan teknik observasi untuk data kualitatif dan tes untuk data kuantitatif. 
Analisis data kuantitatif diperoleh dari hasil tes setelah tindakan dilakukan baik pada siklus I maupun pada siklus II sedang analisis data kualitatif diperoleh dari kegiatan observasi.

Indikator keberhasilan penelitian tindakan kelas ini adalah meningkatnya kualitas pembelajaran PKn pada Siswa Kelas X SMA Negeri 4 Polewali Kabupaten Polewali Mandar yang dapat dilihat dari segi kualitas proses dan kualitas hasil. Dari segi kualitas proses dapat dilihat dari meningkatnya motivasi dan keantusiasan Siswa dalam proses pembelajaran yang meliputi keaktifan, kerjasama, dan sikap. Sedangkan dari kualitas hasil dapat dilihat dari skor rata-rata yang diperoleh Siswa, yaitu mencapai Kriteria Ketuntasan Minimun

(KKM). Menurut Depertemen Pendidikan Nasional ( DEPDIKNAS) Siswa dikatakan tuntas belajar apabila memperoleh skor minimal 65 , selain itu juga dicapai ketuntasan belajar $85 \%$ dari keseluruhan jumlah Siswa setelah diberikan model pembelajaran kooperatif tipe Think Pair Share (TPS).

\section{PEMBAHASAN}

\section{Perencanaan}

Siklus pertama dilaksanakan sebanyak 3 kali pertemuan yang terdiri dari 2 kali pertemuan pembahasan materi dan 1 kali pertemuan pemberian tes dengan kompetensi dasar menguraikan pengertian bangsa dan unsur terbentuknya bangsa melalui penerapan model pembelajaran kooperatif tipe Think Pair Share (TPS). Adapun kegiatan yang dilakukan dalam tahap ini sebagai berikut (a) Membuat lembar observasi untuk mengamati kondisi proses belajar mengajar PKn di kelas dengan menggunakan model pembelajaran kooperatif tipe Think Pair Share (TPS); (b) Membuat Rencana Pelaksanaan Pembelajaran (RPP) dengan mengikuti langkahlangkah pembelajaran kooperatif tipe Think Pair Share (TPS); (c) Membuat media dan perangkat pembelajaran dengan tetap berpedoman pada model pembelajaran kooperatif tipe Think Pair Share (TPS); (d) Merancang dan membuat soal, baik soal untuk latihan di kelas maupun soal untuk pekerjaan rumah (PR); (e) Membuat tes hasil belajar untuk mengukur hasil belajar PKn Siswa.

2. Pelaksanaan

Pelaksanaan penelitian pada siklus I dilaksanakan sebanyak 3 kali pertemuan, yang terdiri dari 2 kali pertemuan untuk materi yaitu pertemuan pertama dengan menguraikan pengertian bangsa dan unsur terbentuknya bangsa dan untuk pertemuan kedua dengan menguraikan pentingnya pengakuan oleh negara lain bagi suatu negara serta 1 kali pertemuan untuk pelaksanaan ulangan atau tes siklus I. Adapun kegiatan yang dilakukan dalam tahap ini sebagai berikut (a) Mengajarkan materi sesuai dengan Rencana Pelaksanaan Pembelajaran (RPP) yang telah dibuat; (b) Setelah presentasi kelompok, peneliti memberikan kesempatan kepada Siswa untuk bertanya mengenai materi pelajaran yang belum mereka pahami; (c) Memberikan kesempatan kepada siswa lain untuk menjawab atau menanggapi, kemudian peneliti menjelaskan hal yang ditanyakan; (d) Pada akhir pertemuan, peneliti dan siswa bersama-sama untuk membuat kesimpulan mengenai materi yang telah dipelajari dan peneliti memberikan tugas pekerjaan rumah (PR) kepada siswa.

\section{Observasi dan Evaluasi}

Observasi merupakan kegiatan pengamatan terhadap keseluruhan proses pembelajaran dalam kelas. Data yang diambil adalah tentang aktivitas Siswa selama mengikuti proses pembelajaran di kelas dengan menerapkan model pembelajaran kooperatif Think Pair Share (TPS)

Berdasarkan hasil analisis data, dapat diketahui bahwa penerapan model pembelajaran kooperatif tipe Think Pair Share (TPS) dapat meningkatkan hasil belajar siswa Kelas X SMA Negeri 4 Polewali Kabupaten Polewali Mandar dalam proses pembelajaran Pendidikan Kewarganegaraan (PKn). Hal ini dapat terjadi karena model pembelajaran kooperatif tipe Think Pair Share (TPS) merupakan model pembelajaran yang memungkinkan Siswa untuk menguatkan, memperluas, menerapkan pengetahuan dan keterampilan akademik mereka dalam berbagai tatanan kehidupan baik di sekolah maupun di luar 
sekolah. Penelitian ini dilaksanakan dalam dua siklus. Pembahasan pelaksanaan tiap siklusnya adalah sebagai berikut:

\section{Pembahasan siklus I}

Dari hasil analisis penelitian, terlihat bahwa pada pelaksanaan pembelajaran Pendidikan Kewarganegaraan (PKn) melalui model pembelajaran Kooperatif tipe Think Pair Share (TPS) pada siklus I hasil tes belajar PKn Siswa Kelas X SMA Negeri 4 Polewali Kabupaten Polewali Mandar berada dalam kategori sedang dengan skor ratarata 56,3 . Sedangkan ketuntasan belajar pada siklus I sebesar 39,1 \% yang masuk kategori tuntas dan $60,9 \%$ yang masuk kategori tidak tuntas, dengan perolehan ketuntasan belajar tersebut berarti belum mencapai ketuntasan belajar $85 \%$ dari keseluruhan jumlah siswa. Hal ini disebabkan dari keaktifan siswa yang kurang optimal selain itu guru masih kurang bisa mengelola kelas, siswa masih enggan bertanya pada guru jika mengalami kesulitan. Adapun kegiatan pembelajaran dengan menggunakan model pembelajaran kooperatif tipe Think Pair Share (TPS) yaitu: Pada awal pembelajaran guru memberikan apersepsi dan motivasi yang berhubungan dengan materi yang akan dibahas agar siswa lebih siap menghadapi bahan pelajaran dan mempunyai rasa ingin tahu yang kuat terhadap materi yang akan dibahas. Kegiatan pendahuluan tersebut diikuti dengan kegiatan inti. Kegiatan inti dalam proses pembelajaran yang dilakukan adalah menjelaskan materi pelajaran setelah itu memberikan suatu masalah/pertanyaan yang berkaitan dengan materi pelajaran selanjutnya meminta siswa menggunakan waktu beberapa menit untuk berpikir jawaban atau masalah tersebut, kemudian membagi siswa dalam kelompok-kelompok secara berpasangan yang terdiri dari 2 Siswa, kemudian guru membagikan tugas, setelah itu siswa secara berpasangan mengerjakan tugas tersebut.

Kemudian masing-masing kelompok mendiskusikan hasil tugasnya. Setiap kelompok diberi kesempatan untuk mempresentasikan hasil pengamatannya kemudian diadakan sharing klasikal dan refleksi. Kegiatan penutup dalam pembelajaran ini berupa diskusi dan menarik simpulan dari materi yang telah dipelajari dengan bimbingan guru. Dalam kegiatan ini siswa diberi kesempatan untuk menanyakan materi yang kurang dipahami siswa, sedangkan guru menyatukan kerangka berpikir Siswa dengan menjelaskan bagian-bagian yang penting.

Dalam kegiatan pengamatan pada saat belajar, diharapkan Siswa dapat menggunakan pengetahuan awalnya untuk membangun pengetahuan baru. Pada kegiatan pengamatan, siswa akan mengalami proses induktif (berdasar fakta nyata) sehingga siswa dapat membangun makna, kesan dalam memori atau ingatannya. Dalam kegiatan diskusi akan menciptakan aktivitas bertanya yang berguna untuk menggali informasi yang dimiliki siswa, mengecek pemahaman, dan membangkitkan respon siswa. Dalam kegiatan diskusi Siswa saling melengkapi hasil temuannya antara satu kelompok dengan kelompok lain. Selain itu, untuk menyamakan konsep antara siswa yang satu dengan Siswa yang lain dan antara guru dengan Siswa dengan memperhatikan keterlibatan dan keaktifan siswa.

\section{Pembahasan siklus II}

Dari hasil analisis penelitian pada proses pembelajaran Pendidikan Kewarganegaraan (PKn) melalui model pembelajaran Kooperatif tipe Think Pair Share (TPS) pada siklus II hasil tes belajar Siswa Kelas $X$ SMA Negeri 4 Polewali Kabupaten Polewali Mandar berada dalam kategori tinggi dengan skor rata-rata 73,0. Sedangkan ketuntasan belajar pada siklus II sebesar $86,9 \%$ yang masuk kategori tuntas dan $13,0 \%$ yang masuk kategori tidak tuntas, dengan perolehan ketuntasan belajar tersebut berarti telah mencapai ketuntasan belajar $85 \%$ dari keseluruhan jumlah Siswa. Jika dibandingkan dengan hasil belajar pada siklus I, hasil belajar pada siklus II mengalami peningkatan. Meningkatnya hasil belajar siswa tersebut dipengaruhi oleh kinerja guru dan keaktifan Siswa dalam proses pembelajaran.

Kinerja guru selama proses pembelajaran siklus II termasuk dalam kriteria sangat baik. Melalui teguran yang tegas, guru dapat mengendalikan Siswa yang ramai sehingga kondisinya lebih kondusif. Guru juga memotivasi 
Siswa supaya aktif bertanya, memberikan tanggapan atau komentar dan menjawab pertanyaan dari guru. Selain itu, guru berkeliling dari satu kelompok ke kelompok lain untuk memberikan bimbingan dan arahan kepada siswa yang masih tampak bingung terhadap materi. Hal ini menyebabakan seluruh kelompok merasa diperhatikan sehingga keaktifan Siswa meningkat.

Dalam proses pembelajaran terjadi peningkatan jumlah Siswa yang aktif mengajukan pertanyaan, tanggapan atau komentar, menjawab pertanyaan, dan mereka juga sudah melakukan kegiatan belajar dengan tertib dan tepat waktu. Terlihat kerjasama kelompok juga menunjukkan peningkatan. Peningkatan banyaknya siswa yang terlibat aktif selama proses pembelajaran merupakan salah satu indikator yang menunjukkan motivasi siswa untuk belajar meningkat. Adanya peningkatan hasil belajar PKn dari siklus I sampai siklus II setelah diterapkan model pembelajaran kooperatif tipe Think Pair Share (TPS). Dengan demikian model pembelajaran kooperatif tipe Think Pair Share (TPS) dapat meningkatkan hasil belajar PKn pada siswa Kelas X SMA Negeri 4 Polewali Kabupaten Polewali Mandar.

Disamping terjadinya peningkatan hasil belajar PKn selama berlangsungnya penelitian dari Siklus I hingga Siklus II, tercatat sejumlah perubahan yang terjadi pada aktivitas belajar siswa pada saat pembelajaran Pendidikan Kewarganegaraan (PKn) melalui model pembelajaran kooperatif tipe Think Pair Share (TPS). Perubahan tersebut merupakan data kualitatif yang diperoleh pada hasil observasi Siswa selama proses pembelajaran berlangsung di kelas. Dari hasil analisis terhadap refleksi dan perubahan siswa dapat disimpulkan ke dalam kategori sebagai berikut (a) Kehadiran siswa pada saat pembelajaran semakin meningkat, hal ini ditandai dengan semakin berkurangnya jumlah siswa yang tidak mengikuti proses pembelajaan di kelas. (b) Motivasi dan minat siswa dalam proses pembelajaran semakin meningkat. Hal ini ditandai dengan semakin banyaknya siswa yang mulai aktif pada pembahasan materi dan mengajukan pertanyaan tentang materi yang kurang dimengerti. Di samping itu siswa juga aktif pada pembahasan soal-soal, menganggapi jawaban dan memberi komentar atas jawaban Siswa yang lain. Sedangkan Siswa yang melakukan kegiatan lain pada saat guru menjelaskan semakin berkurang. (c) Pada awalnya terdapat Siswa yang meminta bimbingan secara langsung dalam mengerjakan soal namun jumlahnya semakin berkurang. Hal ini disebabkan karena pada siklus II siswa dipasangkan dengan tutor sebaya sehingga siswa yang sudah mengerti dapat membimbing temannya yang belum mengerti. (d) Siswa yang mengerjakan pekerjaan rumah (PR) semakin meningkat ini ditandai dengan semakin banyaknya siswa yang mengumpulkan PR pada setiap awal pertemuan, dan (e) Siswa yang keluar masuk pada saat pembelajaran berlangsung semakin berkurang, hal ini ditandai dengan semakin banyaknya siswa yang memperhatikan materi yang diajarkan oleh guru.

\section{KESIMPULAN}

Berdasarkan hasil analisis data dan pembahasan dapat disimpulkan bahwa Penerapan model pembelajaran kooperatif tipe Think Pair Share (TPS) dapat meningkatkan hasil belajar PKn pada Siswa Kelas X SMA Negeri 4 Polewali Kabupaten Polewali Mandar sebagaimana hasil belajar Pendidikan Kewarganegaraan (PKn) setelah pelaksanaan pembelajaran melalui penerapan model pembelajaran kooperatif tipe Think Pair Share (TPS) pada siklus I berada dalam kategori sedang dengan skor rata-rata 56,3 dan meningkat pada siklus II berada dalam kategori tinggi dengan skor rata-rata 73,0. Sedangkan Pada siklus I yang mencapai nilai Kriteria Ketuntasan Minimun (KKM) jumlahnya 9 orang atau 39,1 \% dari 23 siswa. Dan meningkat pada siklus II yang jumlahnya menjadi 20 orang atau $86,9 \%$ dari 23 siswa.

\section{DAFTAR PUSTAKA}

[1] Depertemen Pendidikan dan Kebudayaan. (2003). Kamus Besar Bahasa Indonesia. Edisi Ketiga. Jakarta : Balai Pustaka.

[2] Fathurrahman dan Wuri. (2011). Pembelajaran PKn di Sekolah Dasar. Yogyakarta: Nuha Litera.

[3] Gustaf. (2010). Langkah Cerdas Menjadi Guru Sejati Berprestasi. Yogyakarta : Bahtera Buku. 
[4] Hamzah B.Uno. (2008). Orientasi Baru dalam Psikologi Pembelajaran. Jakarta: Bumi Aksara.

[5] Hasmat. (2011). Meningkatkan Hasil Belajar Matematika Melalui Penerapan Pendekatan Contextual Teaching and Learning Siswa Kelas IV SD Negeri Bontorikong Kecamatan Bontonompo Kabupaten Gowa (Proposal). Universitas Muhammadiyah Makassar.

[6] Kamaruddin. (2010). Pendidikan Kewarganegaraan. Makassar: FKIP Unismuh.

[7] Kunandar. (2007). Guru Profesional Implementasi Kurikulum Tingkat Satuan Pendidikan (KTSP) dan Sukses dalam Sertifikasi Guru. Jakarta : PT.Raja Grafindo Persada.

[8] Mahmudah dan Ridwan. (2010). Evaluasi Pembelajaran Bahasa dan Sastra Indonesia Berbasis KTSP. Diktat. Makassar : Universitas Muhammadiyah Makassar.

[9] Majid. (2006). Perencanaan Pembelajaran. Bandung: PT. Remaja Rodaskarya.

[10] Muslikah. (2010). Sukses Profesi Guru dengan Penelitian Tindakan Kelas. Yogyakarta : Interprebook.

[11] Nana. (2004). Dasar-dasar Proses Belajar Mengajar. Bandung: Sinar Baru Algesindo.

[12] Peraturan Bupati Gowa Nomor 8 Tahun 2008 tentang Pelasanaan Peraturan Daerah Kabupaten Gowa Nomor 4 Tahun 2008 tentang Pendidikan Gratis.

[13] Samrawati. (2011). Meningkatkan Hasil Belajar IPS dengan Materi Keragaman Suku Bangsa dan Budaya di Indonesia dengan Menggunakan Model Pembelajaran Kooperatif Tipe Think Pair Share (TPS) pada Siswa Kelas V SD Inpres Uring Kecamatan Soppeng Riaja Kabupaten Barru (Skripsi).Universitas Muhammadiyah Makassar.

[14] Sudarmin. (2011). PeningkatanHasil Belajar IPA Konsep Sifat-Sifat Cahaya Melalui Metode Eksperimen Pada SiswaKelas V Sd Inpres Rumpia'e Kecamatan Tanete Riaja Kabupaten Barru (Skripsi). Universitas Muhammadiyah Makassar.

[15] Sudjono, A. (1987). Pengantar Statistika Pendidikan. Jakarta: Rajawati.

[16] Tutu, Mustapa. (2017). Penelitian Tindakan Kelas (Teori dan Praktik).Malang.Wineka Media

[17] Tim Penyusun. (2007). Teori Belajar dan Pembelajaran. Diktat. Makassar: Universitas Muhammadiyah Makassar.

[18] Trianto. (2007). Model-model Pembelajaran Inovatif Berorientasi Kontuktivistik. Jakarta: Prestasi Pustaka Publisher.

[19] Tukiran, dkk. (2010). Penelitian Tindakan Kelas. Bandung : Alfabeta.

[20] Undang-undang No. 20 Tahun 2003 tentang Sistem Pendidikan Nasional. 